Article

\title{
Sensory Description of Cultivars (Coffea Arabica L.) Resistant to Rust and Its Correlation with Caffeine, Trigonelline, and Chlorogenic Acid Compounds
}

\author{
Larissa de Oliveira Fassio ${ }^{1, *}$, Marcelo Ribeiro Malta ${ }^{2,+}$, Gladyston Rodrigues Carvalho ${ }^{2, \dagger}$, \\ Gilberto Rodrigues Liska ${ }^{3,+}$, Priscilla Magalhães de Lima ${ }^{1,+}$ and Carlos José Pimenta ${ }^{1,+}$ \\ Received: 30 September 2015; Accepted: 8 January 2016; Published: 18 January 2016 \\ Academic Editor: Benoît Bertrand \\ 1 Department of Food Science, Federal University of Lavras (UFLA), Box 3037, 37200-000 Lavras, MG, Brazil; \\ priscillinha_0487@hotmail.com (P.M.L.); carlospimenta@dca.ufla.br (C.J.P.) \\ 2 Agricultural and Livestock Minas Gerais State Research Institution (EPAMIG), Box 176, 37200-000 Lavras, \\ MG, Brazil; marcelomalta@epamig.ufla.br (M.R.M.); carvalho@epamig.ufla.br (G.R.C.) \\ 3 Department of Exact Science, Federal University of Lavras (UFLA), Box 3037, 37200-000 Lavras, MG, Brazil; \\ gilbertoliska@hotmail.com \\ * Correspondence: larissafassio@yahoo.com.br; Tel.: +55-35-9845-8303 \\ + These authors contributed equally to this work.
}

\begin{abstract}
Considering the importance of the chemical compounds in Arabica coffee beans in the definition of the drink sensory quality and authentication of coffee regions, the aim of this study was to evaluate, from principal component analysis-PCA-if there is a relation between the caffeine, trigonelline, and chlorogenic acid (5-CQA) content and the sensory attributes of the drink, and in this context, enabling the differentiation of cultivars in two coffee-producing regions of Brazil. We evaluated seven rust-resistant Coffea arabica cultivars, and two rust-susceptible cultivars in two cultivation environments: Lavras, in the southern region of Minas Gerais state, and Patrocinio in the Cerrado region of Minas Gerais. The flavor and acidity were determinant for differentiation of the cultivars and their interaction with the evaluated environments. Cultivars Araponga MG1, Catigua MG2, and Catigua MG1 are the most suitable for the production of specialty coffee in the state of Minas Gerais. A poor correlation was found between caffeine, trigonelline, 5-CQA contents, and fragrance, flavor, acidity, body, and final score attributes. However, these compounds enabled the differentiation of the environments. The PCA indicated superiority in the sensory quality of cultivars resistant to rust, compared to the control, Bourbon Amarelo, and Topázio MG1190.
\end{abstract}

Keywords: cultivars; quality drink; principal component analysis; bioactive compounds

\section{Introduction}

The high demand for specialty coffees in international and domestic markets offers a great opportunity to add value to Brazilian coffee, justifying the efforts and strategies that prioritize improving coffee quality [1].

In this context, genetic improvement programs involving Coffea arabica are opting for improved productivity and pathogen resistance allied to drink quality [2]. According to Medina Filho and Bordignon [3] the maximum expression of quality or its specific flavor and aroma potential are basically determined by the genetic constitution of the cultivar.

Theoretically, any Arabica coffee cultivar has the potential for producing a high-quality coffee beverage. However, until recently, there have been paradigms regarding the quality of some hybrids derived from crossings of Coffea arabica and Coffea canephora and other species [2]. Based on criteria 
adopted for the evaluation of specialty coffees, Pereira et al. [4] evaluated Arabica coffee genotypes from the EPAMIG Genetic Improvement Program, and the cultivars Catigua MG2, Catigua MG1, and the progeny H419-6-2-5-3 (all derived from crossing with the "Timor Hybrid") presented scores above 90 points in at least one sample, indicating their great potential for the production of specialty coffees.

The quality of the coffee drink is a highly complex characteristic, and, besides the influence of the genetic component on this characteristic, another determining factor is the cultivation environment [5]. Borém and Friedlander [6] emphasize that Brazil has a plurality of flavors and aromas in its coffees, this being its most notable hallmark. The State of Minas Gerais is a vast territory and has several suitable regions for coffee production with distinct flavors and aromas [7].

In this context, the aim of this study was to investigate the sensory characteristics of rust-resistant arabica coffee cultivars, and if there is a relation between the caffeine, trigonelline, and chlorogenic acid (5-CQA) content, and the sensory attributes of the drink and the effect of the cultivation environment on the characteristics evaluated.

\section{Materials and Methods}

\subsection{Materials}

Were evaluated seven Coffea arabica L. cultivars resistant to rust, developed by the breeding program coordinated by EPAMIG in partnership with the UFV and UFLA, and two rust-susceptible cultivars, which were used as control. The cultivars Bourbon Amarelo and Topázio MG1190 were used as benchmarks for being cultivars traditionally grown in Minas Gerais. The studied cultivars have been established in the field in a randomized block design (RBD) with three replications since 2005, in the south and in the Cerrado of Minas Gerais, corresponding to municipalities of Lavras and Patrocinio, respectively (Table 1).

Table 1. Edaphoclimatic characteristics of each environment.

\begin{tabular}{cccccc}
\hline Enviroments & Altitude & $\begin{array}{c}\text { Average Annual } \\
\text { Temperature }\end{array}$ & $\begin{array}{c}\text { Average Annual } \\
\text { Rainfall }\end{array}$ & Latitude & Longitude \\
\hline Patrocínio & $966 \mathrm{~m}$ & $22^{\circ} \mathrm{C}$ & $1193 \mathrm{~mm}$ & $18^{\circ} 56^{\prime} 38^{\prime \prime} \mathrm{S}$ & $46^{\circ} 59^{\prime} 33^{\prime \prime} \mathrm{W}$ \\
Lavras & $950 \mathrm{~m}$ & $20.4^{\circ} \mathrm{C}$ & $1515 \mathrm{~mm}$ & $21^{\circ} 14^{\prime} 43^{\prime \prime} \mathrm{S}$ & $44^{\circ} 59^{\prime} 59^{\prime \prime} \mathrm{W}$ \\
\hline
\end{tabular}

For a better presentation of the discussion and results, the cultivars were coded as C1-Pau Brasil MG1; C2-Paraíso MGH419-1; C3-Sacramento; C4-Araponga MG1; C5-Oeiras MG6851; C6-Catigua MG1; C7-Catigua MG2; C8-Topázio MG1190, and C9-Bourbon Amarelo, and the environments were classified as A1-Patrocinio and A2-Lavras.

\subsection{Methods}

\subsubsection{Harvesting and Processing}

The coffee cherries were hand-picked and wet processed, yielding peeled cherry coffee (CD). The drying was held immediately following the peeling process in which $8 \mathrm{~L}$ of peeled cherry coffee, from each plot, were arranged uniformly in $1 \mathrm{~m}^{2}$ sieves with screened bottoms on paved yard. The samples were turned 20 times per day until the beans reach an average of $11 \%$ water content (wb). After the drying process the samples were processed and the intrinsic and extrinsic defects removed, minimizing any interference that is not inherent in the genetic material or the cultivation environment.

\subsubsection{Roasting and Sensory Analysis}

The roasting and sensory analysis were performed on flat beans retained in sieve 16 and above, based on the protocols described by the Specialty Coffee Association of America-SCAA. The temperature $\left(160{ }^{\circ} \mathrm{C}-200{ }^{\circ} \mathrm{C}\right)$ and time of roasting were monitored with thermometers and 
chronometers in the time range of eight and $12 \mathrm{~min}$. For sensory analysis, a panel of three trained judges evaluated ten sensorial attributes (fragrance/aroma, consistency, absence of defects, sweetness, flavor, acidity, body, balance, finish, and overall impression), which were recorded on a scale of 0 to 10 points, according to the SCAA [8]. The final sensory score was generated from the sum of the evaluated attributes and specialty coffees are considered those scoring 80 or more points. The descriptions of the sensory characteristics of each sample and analyzed by the judges in accordance with the SCAA protocols were also recorded, allowing a better characterization of cultivars.

\subsubsection{Chemical Analysis}

The extraction of bioactive compounds caffeine, 5-CQA, and trigonelline were conducted according to a methodology adapted from Vitorino et al. [9] by Malta and Chagas [10]. These compounds were determined simultaneously, using high-performance liquid chromatography (HPLC). The system operated with a Shimadzu Prominence injection valve model SIL 20AHT with a $20 \mu \mathrm{L}$ fixed loop and Shimadzu processor. It used a Shimadzu C18 Shim-pack CLC-ODS (M) reverse column (5 $\mu \mathrm{m}$, $4.6 \mathrm{~mm} \times 150 \mathrm{~mm}$ ), with a $4 \mu \mathrm{m}$ pre-column. Elution was isocratic with the mobile phase consisting of methanol: acetic acid: water (25:0.5:74.5), flow rate $1 \mathrm{~mL} / \mathrm{min}$ at $30^{\circ} \mathrm{C}$. The final concentration of caffeine, trigonelline, and 5-CQA were expressed as a percentage of dry matter based on the standard curve of each compound evaluated.

\subsubsection{Statistical Analysis}

The results of the sensory attributes, final scores, caffeine, trigonelline, and 5-CQA were subjected to analysis of variance (ANOVA) and, on detecting significant differences in the F test, the Scott-Knott test was used at $5 \%$ significance. The data were also subjected to multivariate analysis to better understand the effect of the variables. Principal component analysis (PCA) was used for the discrimination of the samples, starting from the interaction between cultivars and environments, resulting in the grouping of scores according to the sensory attributes and chemical composition. For this analysis we used the statistical software R [11].

\section{Results and Discussion}

\subsection{Sensory Analysis}

The two first principal components explained $93.25 \%$ of the variability in responses, showing satisfactory explanation of the variation seen among samples in relation to sensory parameters (Figure 1). The first principal component suggests similarity among points, forming three distinct cultivar $x$ environment groups: the first group (I), with points allocated in the central area of the biplot (A1C1, $\mathrm{A} 1 \mathrm{C} 3, \mathrm{~A} 1 \mathrm{C} 5, \mathrm{~A} 1 \mathrm{C} 9, \mathrm{~A} 2 \mathrm{C} 2, \mathrm{~A} 2 \mathrm{C} 3$, and $\mathrm{A} 2 \mathrm{C} 8$ ); the second group (II) with the points allocated in the left portion of the biplot (A1C2, $\mathrm{A} 1 \mathrm{C} 4, \mathrm{~A} 2 \mathrm{C} 1, \mathrm{~A} 2 \mathrm{C} 4, \mathrm{~A} 2 \mathrm{C} 5, \mathrm{~A} 1 \mathrm{C} 7, \mathrm{~A} 2 \mathrm{C} 7, \mathrm{~A} 1 \mathrm{C} 6$, and $\mathrm{A} 2 \mathrm{C} 6$ ) and a third group positioned in the lower right portion of the biplot (A1C8 and $\mathrm{A} 2 \mathrm{C} 9$ ).

It can be seen that the coffees belonging to Group III (Bourbon Amarelo and Topázio MG1190, in Lavras and Patrocinio environments, respectively) had low correlation with fragrance, taste, acidity, and body and also lower final scores when compared to Group II. These cultivars used as controls for the standard drink and for being cultivars susceptible to rust, showed low correlation with the evaluated sensory attributes, always placing in Group I and III, regardless of the environment studied. Figueiredo et al. [12], from multivariate analysis, also found that the Bourbon genotypes are expressed differently from a sensory point of view, even though the Bourbon cultivar is known worldwide for the production of specialty coffees. For Ferreira et al. [13] not every Bourbon coffee genotype has the same potential for producing special coffee.

Chalfoun et al. [14], on evaluating the sensory characteristics of different Arabica coffee cultivars, also found a superiority of cultivars resistant to rust, compared to the Topázio MG1190 cultivar in Patrocinio. 


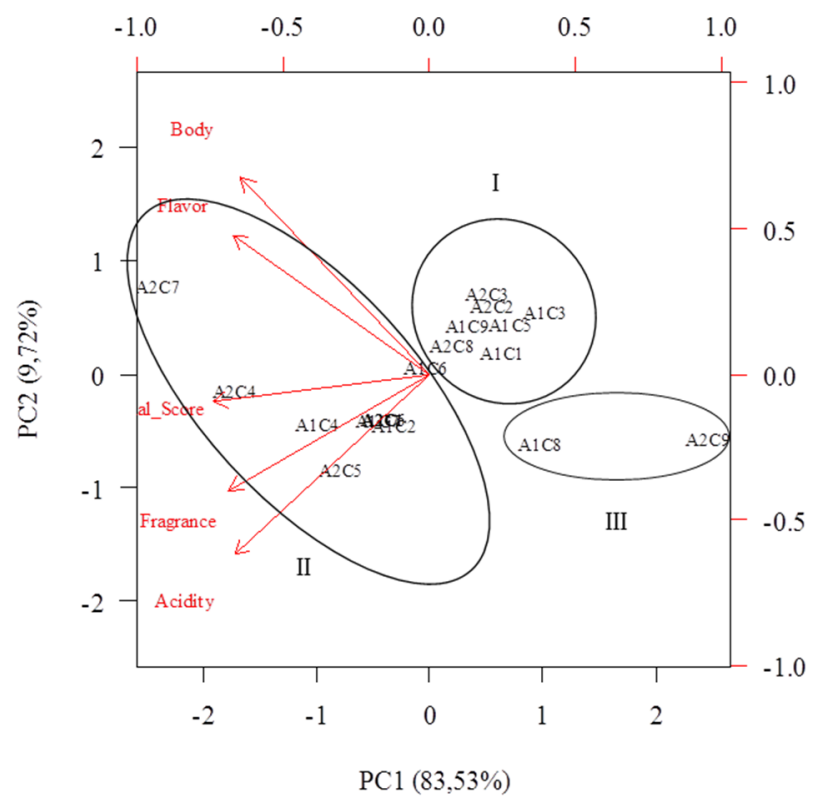

Figure 1. Biplot of the first two axes of the principal component analysis for data from nine cultivars (C) and two environments (A), as a function of the attributes and the final sensory score. C1 = Pau Brasil MG1; C2 = Paraíso MGH419-1; C3 = Sacramento; C4 = Araponga MG1; C5 = Oeiras MG6851; C6 = Catigua MG1; C7 = Catigua MG2; C8 = Topázio MG1190; and C9 = Bourbon Amarelo; A1 $=$ Patrocinio, and A2 = Lavras.

It can be seen that the coffees grouped to the left of the biplot (Group II) showed greater intensity of fragrance, flavor, acidity, and body (Figure 1) and also higher final scores (Table 2). All cultivars allocated in this group had scores above 84 points and, therefore, have potential for production of specialty coffees in the study sites, highlighting the cultivar C7 (Catigua MG2) in Lavras (A2), which had 86.92 points.

Based on Group II, was observed that the cultivars C4, C6, and C7 (Araponga MG1, Catigua MG1, and CatiguaMG2, respectively) had good sensory expression, regardless of the culture environment, in the sense that these cultivars appear all in a group associated with sensory attributes. As for the $\mathrm{C} 1$ and C5 cultivars (Pau Brasil MG1 and Oeiras MG6851) they are expressed best when grown in Lavras and the cultivar Paraíso MGH419-1 (C2) in Patrocinio.

The separation of the points of cultivars and environments into the three distinct groups was considered based on the fact that the genetics of the plant and the environment where it is grown are directly related to the definition of the sensory drink quality [10].

The chemical composition and the drink quality of traditional and hybrid cultivars of $C$. arabica in different countries of Central America were evaluated by Bertrand et al. [15], and the authors also noted that, depending on the planting site, some cultivars, sensorially, had better results than others, whether they are hybrid or not. According to Scholz et al. [16] the same cultivar has different behaviors in different locations, it not being possible to associate specific sensory characteristics for each cultivar. 
Table 2. Results of the sensory attributes and values of trigonelline, 5-CQA, and caffeine of different Arabica coffee cultivars and their interactions with two environments: mean and probability of significance $(F)$ determined by analysis of variance (ANOVA) of two environments and nine cultivars.

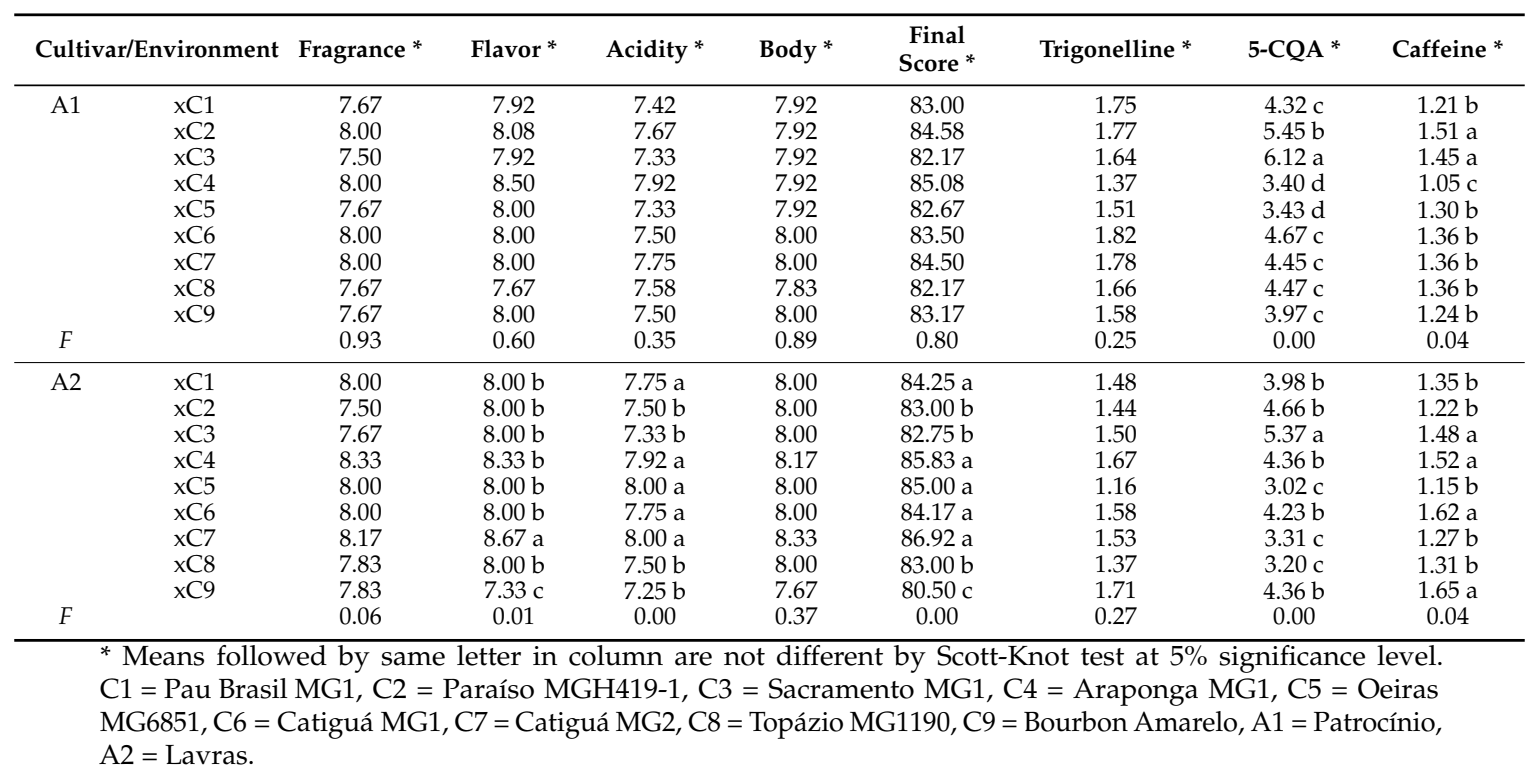

The sensory scores of three jugdes showed that the cultivar Sacramento MG1 (C3), even obtaining scores above 80 (Table 2), did not show positive correlation with the sensory attributes fragrance, flavor, body, and acidity in both studied environments, always being allocated in Group I. This behavior was also observed by Scholz et al. [16], though with different cultivars. The authors report that the IPR 100 and IPR 104 cultivars had lower correlation with the aroma and body attributes in the two environments. This shows that genetics is one of the factors that determine the drink quality of Arabica coffee [17]. Thus, special care is recommended in conducting this cultivar, Sacramento MG1, in both coffee regions studied, to better express its sensory attributes.

The attributes fragrance, flavor, acidity, and body were important in the discrimination of coffees, thus characterizing the first principal component (Table 3) and all of them are correlated between them (Table 4). It is possible to verify the behavior of cultivars, from a sensory point of view, by means of the scores of each sample point, which is formed by the cultivar $x$ environment interaction. Moreover, it can be seen in Table 3 that the first principal component, which has highest proportion of variance explained by data, has the final score with the highest standard deviation and high correlation between another attributes (Table 4). This means that the first component is viewed as a quality coffee indicator according to its sensorial attributes.

Table 3. Descriptive statistics and correlations between the parameters assessed (final score and sensory attributes) with the first two principal components and the respective coefficients of each parameter with the main component.

\begin{tabular}{ccccccc}
\hline \multirow{2}{*}{ Parameters } & \multirow{2}{*}{ Mean } & \multirow{2}{*}{$\begin{array}{c}\text { Standard } \\
\text { Deviation }\end{array}$} & \multicolumn{2}{c}{ PC1 } & \multicolumn{2}{c}{ PC2 } \\
\cline { 4 - 7 } & & & Coefficients & Correlation * & Coefficients & Correlation * \\
\hline Fragrance & 7.833 & 0.262 & -0.450 & $-\mathbf{0 . 9 1 9 2}$ & -0.359 & $-\mathbf{0 . 2 5 0 6}$ \\
Flavor & 8.023 & 0.284 & -0.441 & $-\mathbf{0 . 9 0 1 5}$ & 0.427 & 0.2980 \\
Acidity & 7.611 & 0.243 & -0.435 & $-\mathbf{0 . 8 8 9 4}$ & -0.558 & $-\mathbf{0 . 3 8 9 3}$ \\
Body & 7.977 & 0.133 & -0.423 & $\mathbf{- 0 . 8 6 4 2}$ & 0.608 & 0.4237 \\
Final Score & 83.68 & 1.517 & -0.485 & $\mathbf{- 0 . 9 9 0 4}$ & 0.000 & -0.0587 \\
\hline
\end{tabular}

* Variables in bold and italic indicate groups of variables to be formed, characterized by variables whose correlation with the principal component are high and with the same signal. 
Table 4. Correlations between each parameter assessed (final score and sensory attributes) and results of the Student's $t$-test when population correlation is different from zero.

\begin{tabular}{cccccc}
\hline Parameters & Fragrance & Flavor & Acidity & Body & Final Score \\
\hline Fragrance & 1.000 & $0724^{*}$ & $0.849^{*}$ & $0.701^{*}$ & $0.915^{*}$ \\
Flavor & $0.724^{*}$ & 1.000 & $0.690^{*}$ & $0.823^{*}$ & $0.881^{*}$ \\
Acidity & $0.845^{*}$ & $0.690^{*}$ & 1.000 & $0.614^{*}$ & $0.901^{*}$ \\
Body & $0.701^{*}$ & $0.823^{*}$ & $0.614^{*}$ & 1.000 & $0.821^{*}$ \\
Final Score & $0.915^{*}$ & $0.881^{*}$ & $0.901 *$ & $0.821^{*}$ & 1.000 \\
\hline
\end{tabular}

${ }^{*}$ If $p<0.05$, it rejects null hypothesis that populational correlation is equal to zero.

The fact of all variables are correlated is an important aspect in principal component analysis, however, is necessary to be checked if the correlation matrix is significantly different from zero by the Bartlett test [18]. Then, using the correlation matrix in Table 4, it has showed that the null hypothesis that the correlation matrix is an identity was rejected $(p<0.05)$.

Figures 2 and 3 present the scores of genotype $x$ environment interactions for the first (PC1) and second principal component (PC2), respectively.

For PC1, the A2C7 coffee (Catigua MG2/Lavras) showed a higher negative score, therefore being the coffee with the better sensory attribute and final scores, followed by A2C4 (Araponga/Lavras) coffee. In this case, the Lavras environment, when combined with Catigua MG2 and Araponga MG1 cultivars, stands out for the production of specialty coffees. According to results demonstrated presented by Chagas, Malta and Pereira [19] based on data from 22 cities, the southern region of Minas Gerais has favorable soil and climatic characteristics for the production of top quality coffees.

The A2C8 (Topázio/Lavras), A1C6 (Catigua MG1/Patrocinio) and A1C2 (Paraíso/Patrocinio) coffees can be considered as intermediate coffees, because their scores showed values close to zero.

Furthermore, according to Figure 2, cultivar A2C9 (Bourbon/Lavras) had the highest positive score, and is thus the coffee with the worst sensory and final scores.

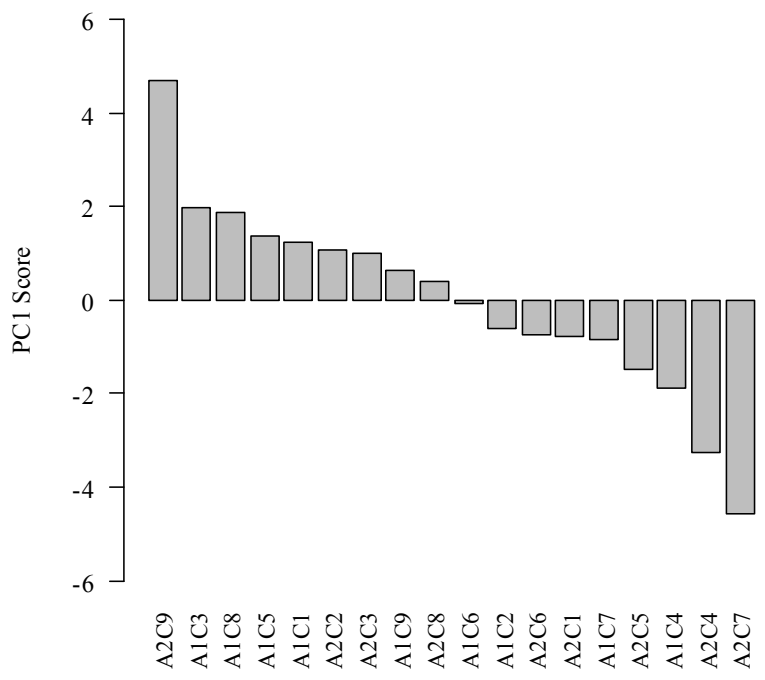

Figure 2. PC1 scores for data from nine cultivars (C) and two environments (A), as a function of the attributes and the final sensory score. C1 = Pau Brasil MG1; C2 = Paraíso MGH419-1; C3 = Sacramento; C4 = Araponga MG1; C5 = Oeiras MG6851; C6 = Catigua MG1; C7 = Catigua MG2; C8 = Topázio MG1190; and C9 = Bourbon Amarelo; A1 = Patrocinio, A2 = Lavras.

The second principal component can be viewed as a comparison of fragrance and acidity scores with the flavor and body scores, because the correlations between these attributes has shown opposite magnitudes and signals. This means that high scores of the first pair imply low scores for the second 
pair, according to the adjusted coefficients of the second major component (Table 3 and Figure 3). Thus, coffees which received similar scores for all four parameters have scores near zero and can be described as coffees with balanced scores. The A1C6 coffees (Catigua MG1/Patrocinio) and A2C4 (Araponga MG1/Lavras) have this characteristic. The A2C7 coffee (Catigua MG2/Lavras) had high values for flavor and body while the A2C5 coffee (Oeiras MG6851/Lavras) showed higher values for the fragrance and acidity attributes (Figure 3).

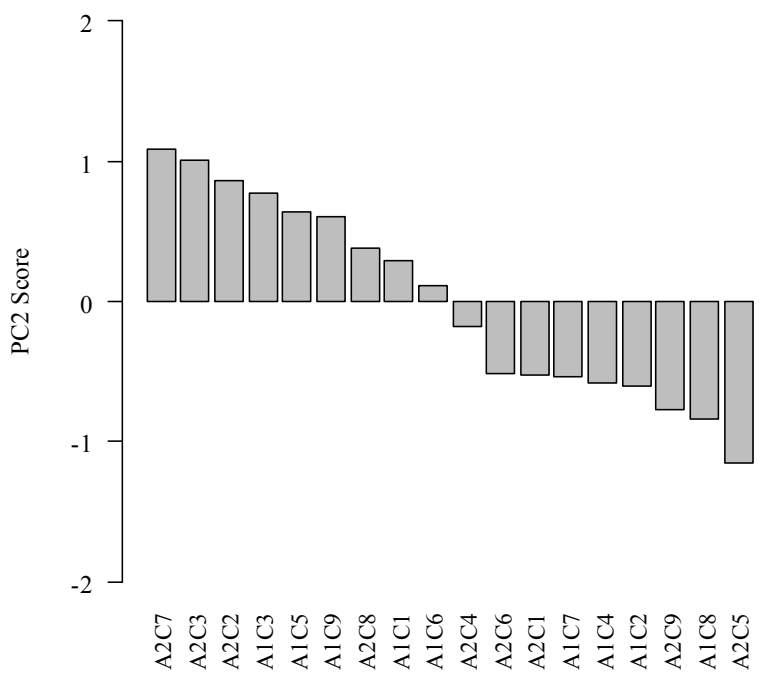

Figure 3. Scores of PC2 for data from nine cultivars (C) and two environments (A), as a function of the attributes and the final sensory score. C1 = Pau Brasil MG1; C2 = Paraíso MGH419-1; C3 = Sacramento; C4 = Araponga MG1; C5 = Oeiras MG6851; C6 = Catigua MG1; C7 = Catigua MG2; C8 = Topázio MG1190; and C9 = Bourbon Amarelo; A1 = Patrocinio, A2 = Lavras.

The cultivar A2C7 (Catigua MG2/Lavras) was described by the three judges as a great coffee, sweet, pleasant, with a sweet caramel aroma, and slight acidity with creamy and velvety body, very sweet fruity flavor, reminiscent of honey and dried fruit. The cultivar A2C4 (Araponga MG1/Lavras) was described as a balanced coffee with floral aromas, lively acidic, and sweet with a soft, velvety body and caramel and milk chocolate flavor.

\subsection{Sensory and Chemical Analysis}

As a next step, this work aimed to relate sensory attributes with chemical characteristics. Thus, it has proceeded to principal component analysis by adding other variables related to bioactive compound results for coffee types analyzed.

The first principal component suggests similarity between points, forming three distinct cultivar and environment groups (Figure 4). The first group (I), with points allocated in the left area of the biplot (A1C4, $\mathrm{A} 2 \mathrm{C} 4, \mathrm{~A} 2 \mathrm{C} 5$, and $\mathrm{A} 2 \mathrm{C} 7$ ); the second group (II) with the points allocated in the right areas of the biplot (A1C1, $\mathrm{A} 1 \mathrm{C} 3, \mathrm{~A} 2 \mathrm{C} 3, \mathrm{~A} 1 \mathrm{C} 5, \mathrm{~A} 1 \mathrm{C} 8, \mathrm{~A} 2 \mathrm{C} 8, \mathrm{~A} 1 \mathrm{C} 9, \mathrm{~A} 2 \mathrm{C} 9$, and $\mathrm{A} 2 \mathrm{C} 2)$ and a third allocated group in central area (A2C1, A1C2, A1C6, A2C6, and A1C7).

The principal component analysis shows that there was counter correlation between the sensory attributes and final sensory score with bioactive compounds caffeine, trigonelline, and 5-CQA. The coffees placed in Group I correlated better with the sensory attributes and final sensory score, and coffees placed in Group III showed intermediary correlation with both parameters. However, the coffees belonging to Group II did not show good correlation with the two parameters evaluated in this study. 


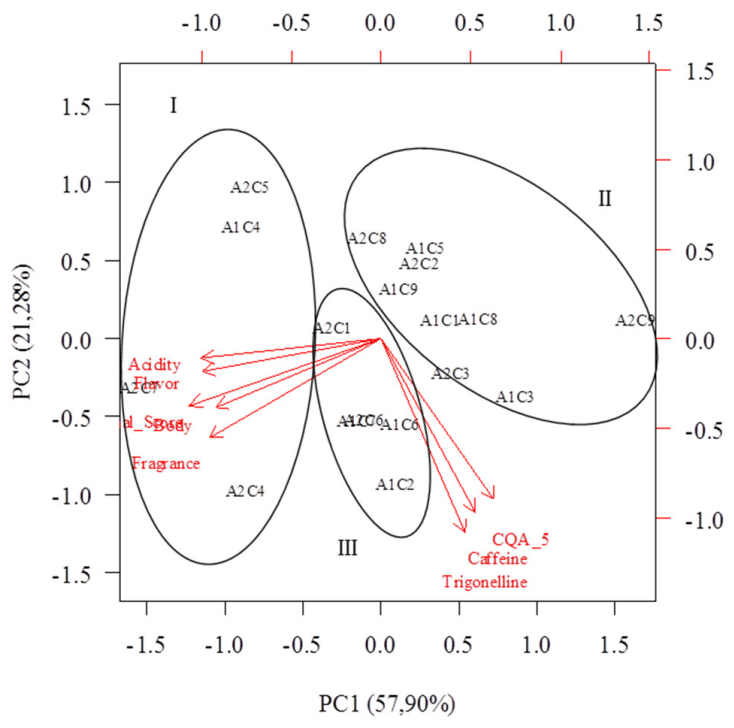

Figure 4. Biplot of the first two axes of the principal component analysis for data from nine cultivars (C) and two environments (A), as a function of the attributes and the final sensory score and of caffeine, trigonelline and 5-CQA.C1 = Pau Brasil MG1; C2 = Paraíso MGH419-1; C3 = Sacramento; C4 = Araponga MG1; C5 = Oeiras MG6851; C6 = Catigua MG1; C7 = Catigua MG2; C8 = Topázio MG1190; and C9 = Bourbon Amarelo; A1 = Patrocinio, A2 = Lavras.

Avelino et al. [20], in studies of quality coffees of two Costa Rica terroirs also report, from the principal component analysis, that it is not possible to correlate these chemical compounds with sensory attributes, and perhaps other chemical compounds, such as amino acids and proteins, would be better related to the attributes in question. Corroborating with the results observed, Franca, Mendonça, and Oliveira [21], analyzing the sensory quality of coffee drinks and Bertrand et al. [15], studying different varieties of $C$. arabica with bioactive compounds, also found no significant relationship between trigonelline and 5-CQA levels and coffee quality. Barbosa et al. (2012) found a negative correlation of caffeine, trigonelline, and 5-CQA, especially the 5-CQA, with the drink quality in work with coffees in the state of Minas Gerais.

Table 5. Descriptive statistics and correlations between the parameters evaluated (final note, sensory attributes, and bioactive compounds) with the first two main components and the respective coefficients for each parameter with the main component.

\begin{tabular}{ccccccc}
\hline \multirow{2}{*}{ Parameters } & \multirow{2}{*}{ Mean } & \multirow{2}{*}{$\begin{array}{c}\text { Standard } \\
\text { Deviation }\end{array}$} & \multicolumn{2}{c}{ PC1 } & \multicolumn{2}{c}{ PC2 } \\
\cline { 4 - 6 } & & & Coefficients & Correlations * & Coefficients & Correlations * \\
\hline Fragrance & 7.833 & 0.262 & -0.398 & $-\mathbf{0 . 8 5 6 5}$ & -0.293 & -0.3822 \\
Flavor & 8.023 & 0.284 & -0.415 & $-\mathbf{0 . 8 9 3 6}$ & 0.000 & -0.1267 \\
Acidity & 7.611 & 0.243 & -0.417 & $-\mathbf{0 . 8 9 7 2}$ & 0.000 & -0.0753 \\
Body & 7.977 & 0.133 & -0.383 & $-\mathbf{0 . 8 2 4 0}$ & -0.202 & -0.2639 \\
Final Score & 83.68 & 1.517 & -0.444 & $-\mathbf{0 . 9 5 5 8}$ & -0.197 & -0.2577 \\
Trigonelline & 1.573 & 0.171 & 0.193 & 0.4160 & -0.574 & $-\mathbf{0 . 7 4 8 7}$ \\
5-CQA & 4.264 & 0.829 & 0.260 & 0.5596 & -0.476 & $\mathbf{- 0 . 6 2 1 2}$ \\
Caffeine & 1.355 & 0.160 & 0.216 & 0.4650 & -0.515 & $\mathbf{- 0 . 6 7 2 6}$ \\
\hline
\end{tabular}

* Variables in bold and italic indicate groups of variables to be formed, characterized by variables whose correlation with principal component are high and with same signal.

The correlations of each characteristic (PC1) and chemical (PC2) are negative (Table 5), indicating that high values of these parameters imply low values of the predicted scores. In the same way that has been seen in sensory analysis, the final score presented the highest standard deviation 
and high correlation between another sensory attribute. However, the sensory attributes presented poor correlation with bioactive compounds (Table 6) and high correlation with the second principal component (Table 5). As in the first case, the first component is viewed as a quality coffee indicator according to its sensorial attributes and the second component is viewed as a chemical compounds coffee indicator.

Table 6. Correlations between each parameter assessed (final score, sensory attributes and bioactive compounds) and results of the Student's $t$-test that population correlation is different from zero.

\begin{tabular}{ccccccccc}
\hline \multicolumn{2}{l}{ Parameters } & Fragrance & Flavor & Acidity & Body & $\begin{array}{c}\text { Final } \\
\text { Score }\end{array}$ & Trigonelline 5-CQA & Caffeine \\
\hline Fragrance & 1.000 & $0724^{*}$ & $0.849^{*}$ & $0.701^{*}$ & $0.915^{*}$ & -0.057 & -0.331 & -0.089 \\
$\quad$ Flavor & $0.724^{*}$ & 1.000 & $0.690^{*}$ & $0.823^{*}$ & $0.881^{*}$ & -0.266 & -0.308 & -0.436 \\
Acidity & $0.845^{*}$ & $0.690^{*}$ & 1.000 & $0.614^{*}$ & $0.901^{*}$ & -0.339 & $-0.476^{*}$ & -0.303 \\
$\quad$ Body & $0.701^{*}$ & $0.823^{*}$ & $0.614^{*}$ & 1.000 & $0.821^{*}$ & -0.187 & -0.259 & -0.214 \\
Final & $0.915^{*}$ & $0.881^{*}$ & $0.901^{*}$ & $0.821^{*}$ & 1.000 & -0.208 & -0.358 & -0.278 \\
$\quad \begin{array}{c}\text { Score } \\
\text { Trigonelline }\end{array}$ & -0.057 & -0.266 & -0.339 & -0.187 & -0.208 & 1.000 & $0.589 *$ & $0.511^{*}$ \\
5-CQA & -0.331 & -0.308 & $-0.476^{*}$ & -0.259 & -0.358 & $0.589^{*}$ & 1.000 & $0.531^{*}$ \\
Caffeine & -0.089 & -0.436 & -0.303 & -0.214 & -0.278 & $0.511^{*}$ & $0.531^{*}$ & 1.000 \\
\hline
\end{tabular}

${ }^{*}$ If $p<0.05$, it rejects null hypothesis that population correlation is equal to zero.

Using the correlation matrix in Table 6, it has showed that the null hypothesis that the correlation matrix is an identity was rejected $(p<0.05)$.

It can be seen that sometimes coffees with high sensory scores exhibited lower, as well higher, values of these chemical compounds (Figures 5 and 6). For example, cultivar C4 (Araponga MG1) exhibits this behavior, and when combined with environment A1 it has lower values of these chemicals and in the environment A2, higher values. However, for the two environments studied it presents higher sensory scores. This behavior was also observed for the C2 cultivar (Paraíso MGH419-1); however, in both environments evaluated, the sensory scores were lower, which denotes the interaction between genes and the environment.

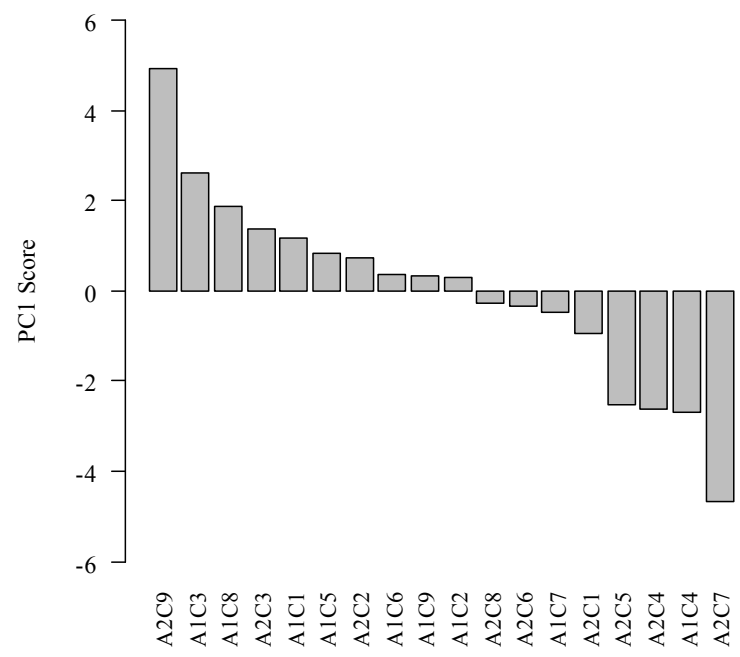

Figure 5. PC1 scores for data from nine cultivars (C) and two environments (A), as a function of the sensory attributes and the final sensory score and of caffeine, trigonelline, and 5-CQA. C1 = Pau Brasil MG1; C2 = Paraíso MGH419-1; C3 = Sacramento; C4 = Araponga MG1; C5 = Oeiras MG6851; C6 = Catigua MG1; C7 = Catigua MG2; C8 = Topázio MG1190; and C9 = Bourbon Amarelo; A1 = Patrocinio, A2 = Lavras. 


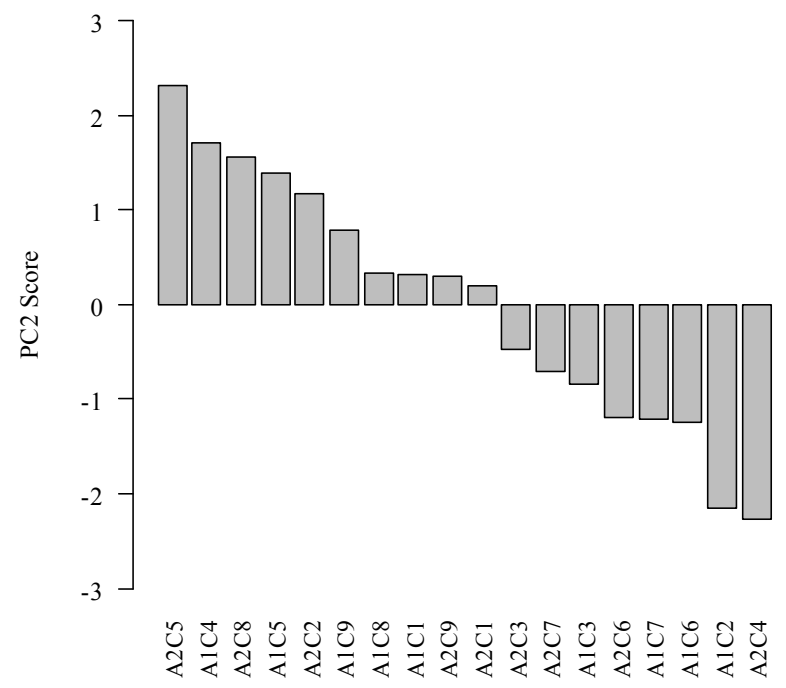

Figure 6. Scores of PC2 for data from nine cultivars (C) and two environments (A), as a function of the sensory attributes and the final sensory score and of caffeine, trigonelline, and 5-CQA. C1 = Pau Brasil MG1; C2 = Paraíso MGH419-1; C3 = Sacramento; C4 = Araponga MG1; C5 = Oeiras MG6851; C6 = Catigua MG1; C7 = Catigua MG2; C8 = Topázio MG1190; and C9 = Bourbon Amarelo; A1 $=$ Patrocinio, A2 = Lavras.

The cultivar C7 (Catigua MG2), identified as one of the cultivars with better characteristics for the production of specialty coffees from both environments, showed higher values (negative direction of the graph) for the compounds caffeine, trigonelline, and 5-CQA, and higher values for the sensory attributes and final sensory score (Figures 5 and 6), indicating the possibility of a positive relation between the variables studied.

Farah et al. [22] reported the relationship between the quality of the beverage and trigonelline content of the raw fruit. The authors found that a reduction of trigonelline levels resulted in reduced beverage quality. However, Figueiredo et al. [12] report that the relationship between sensory quality of coffees and trigonelline, caffeine, and 5-CQA content is still quite contradictory and that further studies on these compounds and their relation with cup quality are required.

It was also observed that there was a distancing between points when considering the variables jointly, i.e., interactions evaluated did not show good similarity. The $\mathrm{A} 1 \mathrm{C} 9$ and $\mathrm{A} 2 \mathrm{C} 9$ points, $\mathrm{A} 1 \mathrm{C} 8$ and $\mathrm{A} 2 \mathrm{C} 8, \mathrm{~A} 1 \mathrm{C} 3$ and $\mathrm{A} 2 \mathrm{C} 3$ (Group II), and $\mathrm{A} 1 \mathrm{C} 4$ and $\mathrm{A} 2 \mathrm{C} 4$ points (Group I) presented this characteristic, since even with being allocated the same groups, they remained far apart. Therefore, these data indicate that the chemical compounds caffeine, trigonelline, and 5-CQA were appropriate discriminators of the environments evaluated, but were not been able to distinguish among genotypes.

As observed in the present study, the caffeine, trigonelline, and chlorogenic acid content allowed the discrimination of Santa Maria de Dota and Orosi environments in Costa Rica [20] and Naranjal, Paraguaicito, and Rosário in Colombia [23].

\section{Conclusions}

The Arabica coffee cultivars, resistant to rust, from the Timor hybrid are potential producers of specialty coffees, especially the Catigua MG2 and Araponga MG1 cultivars evaluated, independent of the environment evaluated.

There is interaction between the genotype and the environment for some cultivars in relation to cup quality and bioactive compounds.

The caffeine, chlorogenic acid, and trigonelline content did not have a good relationship to the sensory attributes. These compounds discriminated Lavras and Patrocinio environments, but were not able to discriminate cultivars. 
Acknowledgments: The authors thank Consórcio Brasileiro de Pesquisa e Desenvolvimento do Café for financial suport and the Empresa de Pesquisa Agropecuária de Minas Gerais for conducting field experiments. The authors also thank the Coordenação de Aperfeiçoamento de Pessoal de Nível Superior-CAPES and the Fundação de Amparo a Pesquisa de Minas Gerais-Fapemig for providing grants.

Author Contributions: Larissa de Oliveira Fassio conducted the whole experimente and wrote the paper. Marcelo Ribeiro Malta, Gladyston Rodrigues Carvalho e Carlos José Pimenta contributed to the guidance, the coffee harvest, conducting chemical analysis and correction of this paper. Gilberto Rodrigues Liska performed the statistical analysis. Priscilla Magalhães de Lima contributed to the development of chemical analysis.

Conflicts of Interest: The authors declare no conflict of interest.

\section{References}

1. Giomo, G.S.; Borém, F.M. Cafés especiais no Brasil: Opção pela qualidade. Infor. Agropecu. 2011, 32, 7-16.

2. Carvalho, G.R.; Rezende, J.C.; Botelho, C.E.; Ferreira, A.D.; Pereira, A.A.; Oliveira, A.C.B. Melhoramento genético do café visando à qualidade de bebida. Inf. Agropecu. 2011, 32, 30-38.

3. Medina Filho, H.P.; Bordignon, R. Rendimento Intrínseco: Um critério adicional para selecionar cafeeiros mais rentáveis. O Agron. 2003, 55, 24-26.

4. Pereira, A.A.; Alvarenga, A.P.; Sakiyama, N.S.; Carvalho, G.R.; Oliveira, A.C.B.; Ribeiro, M.F.; Dias, L.A.S.; Zambolim, L. Cup quality of new cultivars derived from hibrido de timor. In the Proceedings of the International Conference on Coffee Science, Campinas, Brazil, 14-19 September 2008; p. 143.

5. Carvalho, V.D.; Chalfoun, S.M. Aspectos qualitativos do café. Inf. Agropecu. 1985, 11, 79-92.

6. Borém, F.M.; Friedlander, D. Navigating origins. Roast Mag. 2009, 4, 95.

7. Barbosa, J.; Borem, F.; Cirillo, M.; Malta, M.; Alvarenga, A.; Alves, H. Coffee quality and its interactions with environmental factors in Minas Gerais, Brazil. J. Agric. Sci. 2012, 4, 181-190. [CrossRef]

8. Lingle, T.R. The Coffee Cupper's Handbook: Systematic Guide to the Sensory Evaluation of Coffee's Flavor, 4th ed.; Specialty Coffee Association of America: Long Beach, CA, USA, 2011; p. 66.

9. Vitorino, M.D.; França, A.S.; Oliveira, L.S.; Borges, M.L.A. Metodologia de obtenção de extrato de café visando a dosagem de compostos não voláteis. Rev. Bras. Armaz. 2001, 2, 17-24.

10. Malta, M.R.; Chagas, S.J.R. Avaliação de compostos não-voláteis em diferentes cultivares de cafeeiro produzidas na região Sul de Minas Gerais. Acta Sci. Agron. 2009, 31, 57-61. [CrossRef]

11. R Development Core Team. R: A Language and Environment for Statistical Computing; Foundation for Statistical Computing: Vienna, Austria, 2015.

12. Figueiredo, L.P.; Borém, F.M.; Cirillo, M.A.; Ribeiro, F.C.; Giomo, G.S.; Salva, T.J.G. The potencial for high quality bourbon coffees from different environments. J. Agric. Sci. 2013, 5, 87-98.

13. Ferreira, A.D.; Mendes, A.N.G.; Carvalho, G.R.; Botelho, C.E.; Gonçalves, F.M.A.; Malta, M.R. Análise sensorial de diferentes genótipos de cafeeiro Bourbon. Interciencia 2012, 37, 390-394.

14. Chalfoun, S.M.; Pereira, M.C.; Carvalho, G.R.; Pereira, A.A.; Savian, T.V.; dos S. Botelho, D.M. Sensorial characteristics of coffee (Coffea arabica L.): Varieties in the Alto Paranaíba Region. Coffee Sci. 2013, 8, 43-52.

15. Bertrand, B.; Vaast, P.; Alpizar, E.; Etienne, H.; Davrieux, F.; Charmetant, P. Comparison of bean biochemical composition and beverage quality of Arabica hibrids involving sudanese-ethiopian origins with traditional varieties at various elevations in Central America. Tree Physiol. 2006, 26, 1239-1248. [CrossRef] [PubMed]

16. Dos S. Scholz, M.B.; Figueiredo, V.R.G.; Silva, J.V.N.; Kitzberger, C.S.G. Características físico-químicas de grãos verdes e torrados de cultivares de café (Coffea arabica L.) do IAPAR. Coffee Sci. 2013, 6, 245-255.

17. Pereira, M.C.; Chalfoun, S.M.; Carvalho, G.R.; Savian, T.V. Multivariate analysis of sensory characteristics of coffee grains (Coffea arabica L.) in the region of upper Paranaíba. Acta Sci. Agron. 2010, 32, 635-641.

18. Rencher, A.C. Methods of Multivariate Analysis, 2nd ed.; John Wiley: New York, NY, USA, 2002; p. 727.

19. Chagas, S.J.R.; Malta, M.R.; Pereira, R.G.F.A. Potencial da região sul de Minas Gerais para a produção de cafés especiais: I. atividade da polifenoloxidase, condutividade elétrica e lixiviação de potássio. Ciênc. E Agrotec. 2005, 29, 590-597. [CrossRef]

20. Avelino, J.; Barboza, B.; Araya, J.C.; Fonseca, C.; Davrieux, F.; Guyot, B.; Cilas, C. Effects of slope exposure, altitude and yield on coffee quality in two altitude terroirs of Costa Rica, Orosi and Santa María de Dota. J. Sci. Food Agric. 2005, 85, 1869-1876. [CrossRef]

21. Franca, A.S.; Mendonça, J.C.F.; Oliveira, S.D. Composition of green and roasted coffees of different cup qualities. LWT Food Sci. Technol. 2005, 38, 709-715. [CrossRef] 
22. Farah, A.; Monteiroa, M.C.; Caladob, V.; Francac, A.S.; Trugoa, L.C. Correlation between cup quality and chemical attributes of Brazilian coffee. Food Chem. 2006, 98, 373-380. [CrossRef]

23. Bertrand, B.; Villarreal, D.; Laffargue, A.; Posada, H.; Lashermes, P.; Dussert, S. Comparison of the effectiveness os fatty acids, chlorogenic acids, and elements for the chemometric discrimation of coffee (Coffea Arabica L.) varieties and growing origins. J. Agric. Food Chem. 2008, 56, 2273-2280. [CrossRef] [PubMed]

(c) 2016 by the authors; licensee MDPI, Basel, Switzerland. This article is an open access article distributed under the terms and conditions of the Creative Commons by Attribution (CC-BY) license (http:/ / creativecommons.org/licenses/by/4.0/). 